\title{
Structural, vibrational, NMR, quantum chemical, DNA binding and protein docking studies of two flexible imine oximes
}

\author{
YUNUS KAYA a,b \\ ${ }^{a}$ Department of Chemistry, Faculty of Arts and Sciences, Uludag University, 16059 Bursa, Turkey \\ ${ }^{b}$ Department of Chemistry, Faculty of Natural Sciences, Architecture, and Engineering, Bursa Technical \\ University, 16190 Bursa, Turkey \\ e-mail: ykaya@uludag.edu.tr; yunus.kaya@btu.edu.tr
}

MS received 24 November 2015; revised 27 March 2016; accepted 3 July 2016

\begin{abstract}
Two flexible imine oxime molecules, namely, 3-(pyridin-2-ylmethylimino)-butan-2-one oxime $\left(\mathrm{HL}^{1}\right)$ and 3-(pyridin-2-ylmethylimino)-pentan-2-one oxime $\left(\mathrm{HL}^{2}\right)$ have been synthesized and characterized by elemental analysis, IR and NMR techniques. The conformational behavior was investigated using the density functional theory (DFT) with the B3LYP method combined with the 6-311++G(d,p) basis set. As a result of the conformational studies, three stable molecules and the most stable conformer were determined for the both imine oximes. The spectroscopic properties such as vibrational and NMR were calculated for the most stable conformer of the $\mathrm{HL}^{1}$ and $\mathrm{HL}^{2}$. The calculation results were applied to simulate infrared spectra of the title compounds, which show good agreement with observed spectra. In addition, the stable three molecules of the both imine oximes have been used to carry out DNA binding and protein docking studies with DNA and protein structures (downloaded from Protein Data Bank) using Discovery Studio 3.5 to find the most preferred binding mode of the ligands inside the DNA and protein cavity.
\end{abstract}

Keywords. Imine oxime; DFT calculation; spectroscopic properties; DNA binding; protein binding.

\section{Introduction}

Imine oximes are the derivatives of oximes which act as excellent bidentate and chelating ligands from nitrogen donor atoms of imine and oxime groups. ${ }^{1-9}$ These molecules and their coordination compounds continue to attract considerable attention in DNA bounding studies. ${ }^{10-13}$ In the most basic sense, biological active molecules are complementary in shape and charge to the biomolecular targets with which they interact and therefore will bind to them. Imine oximes are significant biologically active molecules that contain the groups enabling strong interaction with biomolecules, such as DNA and protein.

In recent years, some theoretical approaches such as density functional theory (DFT) and DNA/protein docking methods have been widely used in theoretical modeling of oximes. ${ }^{14-20}$ The rapid development of theoretical methods has made it possible to calculate many molecular properties with accuracies comparable to those of traditional correlated theoretical methods, at more favorable computational costs. ${ }^{21}$ Although theoretical studies of oximes have been intensively worked out, quantum chemical studies of imine oximes have received less interest. In addition, the interactions of imine oximes with DNA and proteins were not found in the literature.
In this study, two flexible imine oximes, namely, 3-(pyridin-2-ylmethylimino)-butan-2-one oxime (HL $\left.{ }^{1}\right)$ and 3-(pyridin-2-ylmethylimino)-pentan-2-one oxime $\left(\mathrm{HL}^{2}\right)$ heve been synthesized and characterized by elemental analysis, IR and NMR techniques. The cisoid and transoid conformations of $E$ - and $Z$-isomers of $\mathrm{HL}^{1}$ and $\mathrm{HL}^{2}$ have been identified using B3LYP/6$311++\mathrm{G}(\mathrm{d}, \mathrm{p})$ level. The vibrational and NMR spectra were computed at this level and compared with the experimental results. The interactions of $\mathrm{HL}^{1}$ and $\mathrm{HL}^{2}$ with DNA and protein were investigated systematically. The molecular docking has been employed to get information about the interaction of $\mathrm{HL}^{1}$ and $\mathrm{HL}^{2}$ for different conformers with B-DNA and Human Serum Albumin (HSA). These calculations are valuable for providing insight into molecular properties of imine oxime compounds.

\section{Experimental and computational methods}

\subsection{Materials and Methods}

The elemental analyses $(\mathrm{C}, \mathrm{H}$ and $\mathrm{N})$ were performed using a EuroEA 3000 CHNS elemental analyser. IR spectra of molecules were recorded as $\mathrm{KBr}$ pellets on a Thermo Nicolet 6700 FT-IR spectrophotometer in the frequency range of $4000-400 \mathrm{~cm}^{-1}$. ${ }^{1} \mathrm{H}$ NMR 
(400 MHz) and ${ }^{13} \mathrm{C}$ NMR (100 MHz) spectra were recorded on a Varian Mercury plus spectrometer in DMSO- $d_{6}$ and TMS was used as an internal standard.

\subsection{Synthesis}

The two imine oximes were prepared by refluxing a mixture of a solution containing respective carbonyl oximes $(0.51 \mathrm{~g}$, butandionmonooxime; $0.58 \mathrm{~g}$, pentandionmonooxime; $5 \mathrm{mmol}$ ) in $10 \mathrm{~mL}$ of $\mathrm{EtOH}$ and a solution containing 2-aminomethylprydine $(0.52 \mathrm{~mL}$, $5 \mathrm{mmol}$ ) in $5 \mathrm{~mL}$ of EtOH. The reaction mixture was stirred for $3 \mathrm{~h}$ under reflux.

2.2a $H L^{1}$ : [Yield: $0.87 \mathrm{~g}, 91 \%$ ] Analysis: Calculated (\%) for $\mathrm{C}_{10} \mathrm{H}_{13} \mathrm{~N}_{3} \mathrm{O}$ : C, 62.81; H, 6.85; N, 21.97. Found(\%): C, 62.90; H, 6.63; N, 21.94. ${ }^{1} \mathrm{H}$ NMR $\left(\right.$ DMSO-d $\left._{6}\right): \delta($ in ppm) $10.96(s, 1 \mathrm{H}), 8.49-7.20(m$, $4 \mathrm{H}), 4.79(s, 2 \mathrm{H}), 1.81(s, 3 \mathrm{H}), 1.14(s, 3 \mathrm{H}) .{ }^{13} \mathrm{C} \mathrm{NMR}$ $\left(\right.$ DMSO$^{-d_{6}}$ ): $\delta$ (in ppm) $169.2,159.2,154.9,148.6$, 136.7, 123.1, 122.9, 57.9, 16.5, 11.8, MS (EI, $m / z)$ 191.9 [M+; calcd. for $\mathrm{C}_{10} \mathrm{H}_{15} \mathrm{~N}_{3} \mathrm{O}:$ 191.11].

2.2b $H L^{2}$ : [Yield: $0.90 \mathrm{~g}, 88 \%$ ] Analysis: Calculated (\%) for $\mathrm{C}_{11} \mathrm{H}_{15} \mathrm{~N}_{3} \mathrm{O}: \mathrm{C}, 64.37 ; \mathrm{H}, 7.37 ; \mathrm{N}, 20.47$. Found (\%): C, 64.30; H, 7.19; N, 20.41. ${ }^{1} \mathrm{H}$ NMR (DMSO$\left.\mathrm{d}_{6}\right): \delta($ in ppm) $10.77(s, 1 \mathrm{H}), 8.56-7.11(m, 4 \mathrm{H}), 4.88$ $(s, 2 \mathrm{H}), 2.68(m, 2 \mathrm{H}), 2.18(t, 3 \mathrm{H}), 1.02(s, 3 \mathrm{H})$. ${ }^{13} \mathrm{C}$ NMR (DMSO-d 6 ): $\delta$ (in ppm) 170.6, 160.4, 157.0, 148.5, 137.1, 122.1, 121.9, 56.1, 20.8, 11.3, 9.4, MS (EI, $m / z) 205.9$ [M+; calcd. for $\mathrm{C}_{10} \mathrm{H}_{15} \mathrm{~N}_{3} \mathrm{O}$ : 205.12].

\subsection{Computational methods}

All calculations were conducted using DFT with the Becke-Lee-Yang-Parr functional (B3LYP) method ${ }^{22}$ as implemented in the GAUSSIAN 03 program package. ${ }^{23}$ In the first step of the calculation, to elucidate conformational features of the $\mathrm{HL}^{1}$ and $\mathrm{HL}^{2}$, the selected degree of torsional freedom, T(N1-C1-C2$\mathrm{N} 2$ ), was varied from $-180^{\circ}$ to $+180^{\circ}$ in interval of $10^{\circ}$ and the potential energy curve (PES) was obtained with the B3LYP/6-311++G(d,p) level of theory in the gas phase. In the potential energy curve, the stationary points were confirmed by the frequency analysis as minima with all real frequency and with no imaginary frequency, implying absence of transition state. For the three lowest energy conformers, the geometric structure was reoptimized at the DFT level of theory by using 6$311++G(d, p)$ level. For all of the calculations in this study, optimized structural parameters were used.

The harmonic vibrational frequencies were calculated at the same level of theory in the gas phase for the optimized structures, and the obtained frequencies were scaled by $0.958^{24}$ for $4000-1700 \mathrm{~cm}^{-1}$ and $0.978^{25}$ for $1700-400 \mathrm{~cm}^{-1}$ ranges, respectively. Furthermore, theoretical vibrational spectra of the $\mathrm{HL}^{1}$ and $\mathrm{HL}^{2}$ were interpreted by means of PEDs using VEDA 4 program. ${ }^{26}$

${ }^{1} \mathrm{H}$ and ${ }^{13} \mathrm{C}$ NMR chemical shifts $\left(\delta_{\mathrm{H}}\right.$ and $\left.\delta_{\mathrm{C}}\right)$ of $\mathrm{HL}^{1}$ and $\mathrm{HL}^{2}$ were calculated using the GIAO method ${ }^{27}$ in $\mathrm{CDCl}_{3}$ at the B3LYP/6-311++G(d,p) level and using the TMS shielding calculated as a reference.

\subsection{Molecular docking details}

Molecular docking studies were performed using Autodock/Vina program. ${ }^{28}$ The PDB formats of $\mathrm{HL}^{1}$ and $\mathrm{HL}^{2}$ were obtained by converting their 'out' files using Autodock software. The crystal structures of BDNA (PDB ID: 1BNA) and HSA (PDB ID: 1H9Z) were retrieved from the Protein Data Bank. Visualization of the docked systems was performed using Discovery Studio 3.5 software. The binding sites were centered on the DNA and HSA, and a grid box was created with $60 \times 60 \times 60$ points and a $0.375 \AA$ grid spacing in which almost the entire macromolecule was involved. All other parameters were kept at their default values.

\section{Results and Discussion}

The $\mathrm{HL}^{1}$ and $\mathrm{HL}^{2}$ were synthesized by the reaction of carbonyl oxime (butandionmonooxime for $\mathrm{HL}^{1}$ and pentandionmonooxime for $\mathrm{HL}^{2}$ ) with 2-aminomethylprydine in the EtOH solution. The $\mathrm{HL}^{1}$ and $\mathrm{HL}^{2}$ were obtained in high yields (91 and $88 \%$, respectively). The structures of $\mathrm{HL}^{1}$ and $\mathrm{HL}^{2}$ were fully characterized by spectral and elemental analysis data. The elemental analysis details (as seen in Table S1 in Supplementary Information) showed that the imine oximes, namely $\mathrm{HL}^{1}$ and $\mathrm{HL}^{2}$ are formed as seen in Scheme 1. In addition, the carbonyl stretching vibration of the carbonyl oximes which are butandionmonooxime and pentandionmonooxime was observed at ca. $1670 \mathrm{~cm}^{-1}$ in the IR spectra. This stretching vibration disappeared in the spectra of the imine oximes, and in its place, the streching vibration of imine was observed at ca. 1628 $\mathrm{cm}^{-1}$ as the strongest band. In the ${ }^{13} \mathrm{C}$ NMR spectrum, the carbon resonance of the $\mathrm{C}=\mathrm{O}$ group in the carbonyl oximes is observed at ca. $200 \mathrm{ppm}$. This signal also disappeared in the spectra of imine oximes, and instead of this signal, the carbon resonance of $\mathrm{C}=\mathrm{N}$ group occurs at ca. $170 \mathrm{ppm}$. In addition, the mass spectra of $\mathrm{HL}^{1}$ and $\mathrm{HL}^{2}$ exhibit molecular ions at $m / z 191.9$ (191.11) and 205.9 (205.12) $[\mathrm{M}]^{+}$. These results indicate the formations of both imine oximes. 

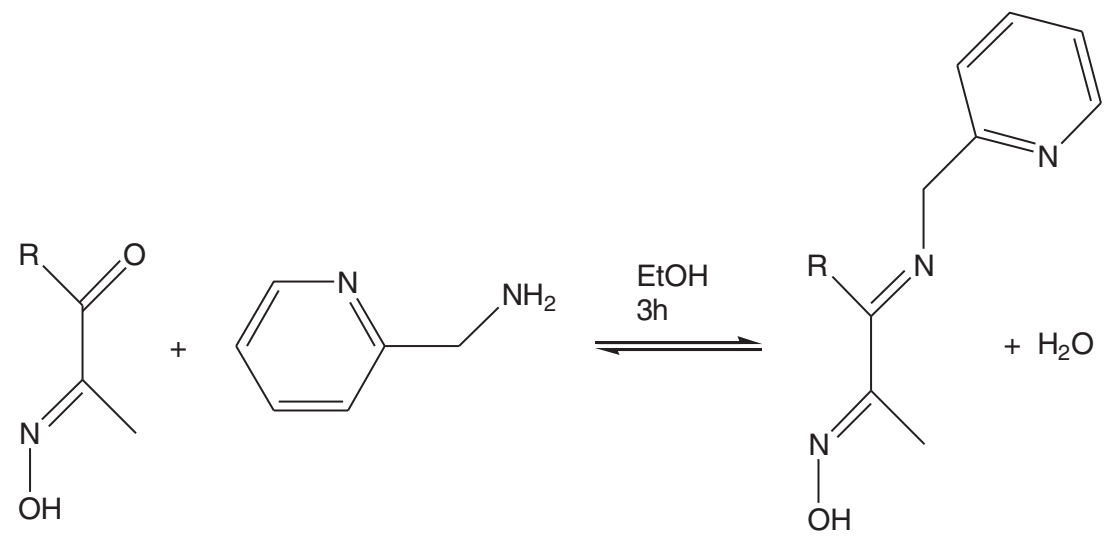

$\mathrm{R}=-\mathrm{CH}_{3}$ for $\mathrm{HL}^{1} ;-\mathrm{CH}_{2} \mathrm{CH}_{3}$ for $\mathrm{HL}^{2}$

Scheme 1. Synthesis of $\mathrm{HL}^{1}$ and $\mathrm{HL}^{2}$.

3.0a Conformational analysis: The structures of $\mathrm{HL}^{1}$ and $\mathrm{HL}^{2}$ are very flexible and represented by several conformations. To establish the most stable conformations, the molecules were subjected to a conformation analysis around the free rotation bonds. The structures of $\mathrm{HL}^{1}$ and $\mathrm{HL}^{2}$ represent several conformations as illustrated in Figure 1.

Conformations of these molecules are feasible depending on the orientation around $\mathrm{C} 1-\mathrm{C} 2$ bond. Conformational analyses were carried out for $\mathrm{HL}^{1}$ and $\mathrm{HL}^{2}$ by potential energy surface scan to find all possible conformers with B3LYP method using 6-311++G(d,p) basis set. The stable three molecules for both imine oximes were determined; they are two s-cis and one $s$-trans isomers as seen in Figure 1. All the possible geometries of the conformers were optimized to find out the most stable configuration of both compounds. Thus, the s-trans isomer is determined to be the most stable isomer for both imine oximes, for which dihedral angles, N1-C1-C2-N2 were at ca. $-178^{\circ}$. The most stable conformers of $\mathrm{HL}^{1}$ and $\mathrm{HL}^{2}$ were then subjected to geometrical optimization by B3LYP method using $6-311++\mathrm{G}(\mathrm{d}, \mathrm{p})$ basis set to obtain geometrical parameters, vibrational frequencies and NMR spectra. The numbering of atoms of the most stable conformers for both imine oximes is shown in Figure 2.

\subsection{Vibrational spectroscopy}

Vibrational assignments were carried out by DFT calculations using the B3LYP method with a 6$311++\mathrm{G}(\mathrm{d}, \mathrm{p})$ basis set using the structural geometry obtained by the same method, along with the experimental values and assignments, and these are presented in Table S2 (in Supplementary Information). The experimental and theoretical spectra of the $\mathrm{HL}^{1}$ and $\mathrm{HL}^{2}$ are
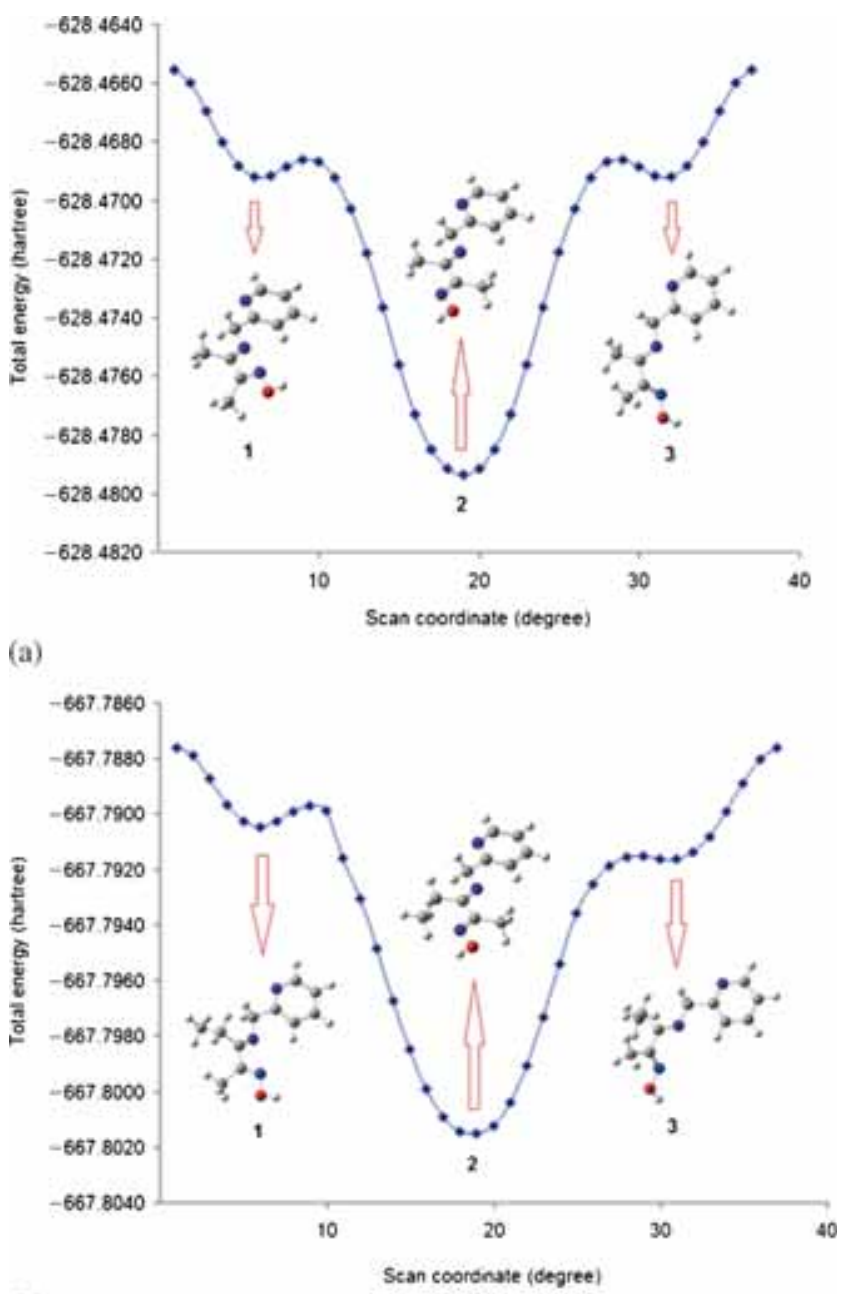

(b)

Figure 1. Potential energy surfaces of (a) $\mathrm{HL}^{1}$ and (b) $\mathrm{HL}^{2}$ calculated at the level of B3LYP/6-311++G(d,p).

shown in Figures S2 and S3 (Supplementray Information). $\mathrm{HL}^{1}$ and $\mathrm{HL}^{2}$ consist of 27 and 30 atoms, respectively, and belong to $C_{1}$ point group, and hence the 

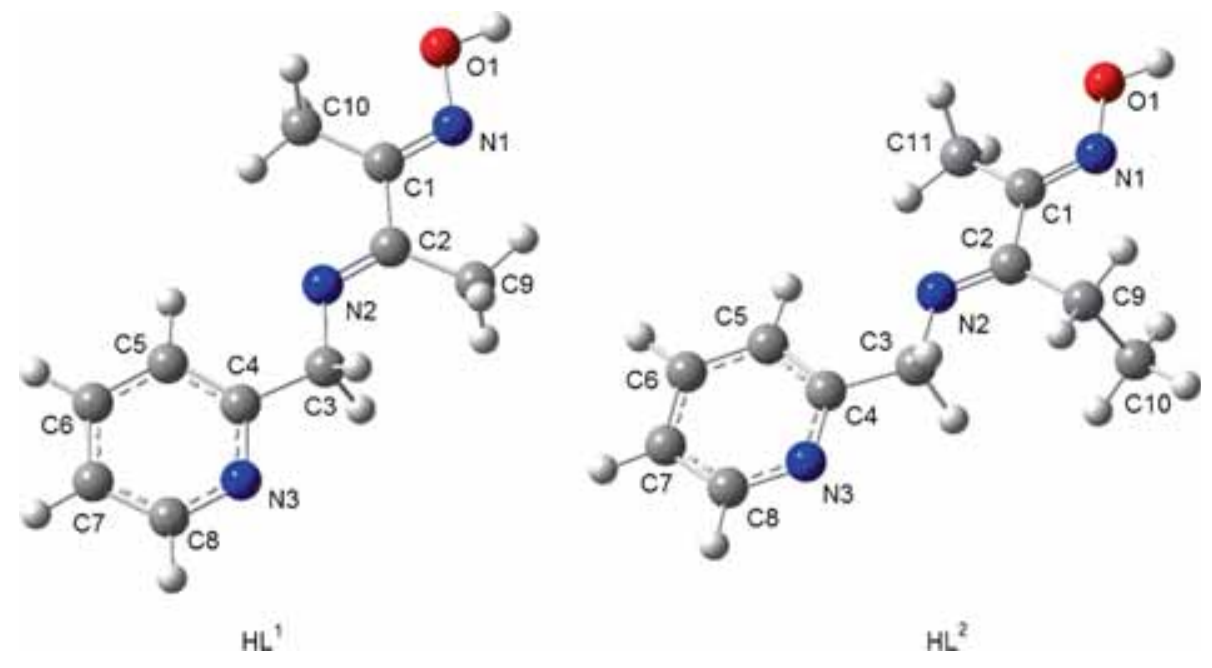

Figure 2. Optimized structures and the numbering of atoms for the most stable conformers.

75 and 84 fundamental modes of vibrations are distributed as $\Gamma_{\text {vib }}=52 \mathrm{~A}^{\prime}+23 \mathrm{~A}^{\prime \prime}$ for $\mathrm{HL}^{1}$ and $\Gamma_{\text {vib }}=$ $58 \mathrm{~A}^{\prime}+26 A^{\prime \prime}$ for $\mathrm{HL}^{2}$. In order to fit the theoretical and experimental wavenumbers, the theoretical values were scaled using suitable scaling factors and the scaling factors are $0.958^{24}$ for $4000-1700 \mathrm{~cm}^{-1}$ and $0.978^{25}$ for $1700-400 \mathrm{~cm}^{-1}$ ranges. In general, the absorption frequencies obtained from experiment and theory are in good agreement.

3.1a The $\mathrm{OH}$ vibrations: The $\mathrm{OH}$ vibrations were generally observed between $3600-3200 \mathrm{~cm}^{-1} \cdot{ }^{29-34}$ Manimekalai and Balachander ${ }^{35}$ observed the $\mathrm{OH}$ stretching vibrations in 2-(ethoxycarbonylmethoxy)-5(arylazo)benzaldehydes and their oximes between 3251 and $3431 \mathrm{~cm}^{-1}$. In $\mathrm{HL}^{1}$ and $\mathrm{HL}^{2}$, the $\mathrm{OH}$ stretching vibrations were observed as broad bands at 3243 and $3238 \mathrm{~cm}^{-1}$, while calculated values are 3667 and 3668 $\mathrm{cm}^{-1}$, respectively. Due to the nature of this vibration mode, its frequency is very sensitive in the crystalline state, in which the hydrogen bonding interactions involving this group are present as discussed above. On the other hand, single molecule was used in the DFT calculations, and thus much larger deviations from the experimental values are observed. This difference between experimental and calculated results is consistent with those reported for similar molecules. ${ }^{36,37}$ Similarly, the in-plane and out-of-plane $\mathrm{OH}$ bending vibrations are expected at $1350-1100 \mathrm{~cm}^{-1}$ and $900-$ $600 \mathrm{~cm}^{-1},{ }^{38}$ respectively. The in-plane vibrations were found at 1348 and $1072 \mathrm{~cm}^{-1}$ for $\mathrm{HL}^{1}$, and $1352 \mathrm{~cm}^{-1}$ for $\mathrm{HL}^{2}$, which are in the expected range. In the same way, the out-of-plane vibrations were observed at 617 and $621 \mathrm{~cm}^{-1}$ for both imine oximes, while calculated value is $626 \mathrm{~cm}^{-1}$. 3.1b The $\mathrm{CH}$ vibrations: The $\mathrm{CH}$ stretching vibrations of the pyridine ring were normally observed in the region $3100-3000 \mathrm{~cm}^{-1}$. ${ }^{39-42} \mathrm{In} \mathrm{HL}^{1}$ and $\mathrm{HL}^{2}$, nine and twelve $\mathrm{CH}$ stretching bands were calculated in the spectra of the both molecules, respectively, and three of which belong to the pyridine rings. They appeared as weak bands in the frequency range $3057-3013 \mathrm{~cm}^{-1}$ for both molecules. ${ }^{39,40}$ The aliphatic $\mathrm{CH}$ stretching vibrations calculated at 2962, 2948, 2916, 2904, 2882 and $2857 \mathrm{~cm}^{-1}$ were observed at 2956, 2929 and $2907 \mathrm{~cm}^{-1}$ for the $\mathrm{HL}^{1}$. Similarly, the nine aliphatic $\mathrm{CH}$ stretching vibrations calculated between 2985 and $2865 \mathrm{~cm}^{-1}$ were observed at 2968, 2949, 2902 and $2886 \mathrm{~cm}^{-1}$ for $\mathrm{HL}^{2}$. These results indicate that the observed and calculated values of the $\mathrm{CH}$ stretching are consistent with the literature in which the aliphatic $\mathrm{C}-\mathrm{H}$ stretching generally occurs below $3000 \mathrm{~cm}^{-1} \cdot{ }^{41,42}$ In-plane and out-of-plane bending vibrations for aromatic and aliphatic $\mathrm{CH}$ are expected to occur as strong to weak intensity bands in the region 1300-1200 and 1000$800 \mathrm{~cm}^{-1},{ }^{43-47}$ respectively. The in-plane bending bands were calculated at ca. $1470-1040 \mathrm{~cm}^{-1}$ for both imine oximes, while the corresponding out-of-plane vibrations were calculated at ca. $963-511 \mathrm{~cm}^{-1}$ for $\mathrm{HL}^{1}$ and $957-532 \mathrm{~cm}^{-1}$ for $\mathrm{HL}^{2}$. The in-plane and out-of-plane $\mathrm{CH}$ vibrations of the both imine oximes are well within the general expected range. ${ }^{36,37}$ All these variations are logically due to $\mathrm{CC}, \mathrm{NO}$, and $\mathrm{CN}$ modes in the oxime and prydine groups whose in-plane and out-of-plane bending vibrations are within these ranges.

3.1c The CC vibrations: The $\mathrm{CC}$ stretching vibrations for pyridine ring are generally observed between $1600-1400 \mathrm{~cm}^{-1} \cdot{ }^{39-42}$ In this study, we observed two $\mathrm{CC}$ bands in both imine oximes, and these bands were 
calculated at 1594 and $1577 \mathrm{~cm}^{-1}$ in the $\mathrm{HL}^{1}, 1591$ and $1575 \mathrm{~cm}^{-1}$ in the $\mathrm{HL}^{2}$, while the $\mathrm{CC}$ stretchings were observed at 1582 and $1579 \mathrm{~cm}^{-1}$, respectively, for both imine oximes. All the CC bands are well within the expected range. ${ }^{39-42}$ The in-plane and out-of-plane bending vibrations of the $\mathrm{CC}$ bond are calculated between 996 and $411 \mathrm{~cm}^{-1}$ for both imine oximes. These results also are in agreement with the cited literature. ${ }^{36,37}$

3.1d The CN vibrations: The mixing of several bands causes the identification of $\mathrm{CN}$ vibrations very difficult in many molecules. Frequency $\sim 1600 \mathrm{~cm}^{-1}$ indicates $\mathrm{CN}$ double bond while frequency $\sim 1300 \mathrm{~cm}^{-1}$ indicates the presence of $\mathrm{CN}$ single bond. ${ }^{36,37}$ The $\mathrm{CN}$ bands, which are imine and oxime groups, were observed at 1628 and $1600 \mathrm{~cm}^{-1}$ in $\mathrm{HL}^{1}$ and 1626 and $1599 \mathrm{~cm}^{-1}$ in $\mathrm{HL}^{2}$ as sharp bands and the calculated values of this mode were somewhat shifted to the higher frequency, appearing at 1647 and $1637 \mathrm{~cm}^{-1}$ in $\mathrm{HL}^{1}$ and 1652 and $1540 \mathrm{~cm}^{-1}$ in $\mathrm{HL}^{2}$, respectively. Similarly the out-of-plane bending vibrations were calculated at ca. $462 \mathrm{~cm}^{-1}$, while these values for this mode were observed at 453 and $472 \mathrm{~cm}^{-1}$, respectively, for $\mathrm{HL}^{1}$ and $\mathrm{HL}^{2}$.

3.1e The NO vibrations: The characteristic group frequencies of the NO are usually independent of the rest of the modes in the molecule. The NO stretching was observed at $1013 \mathrm{~cm}^{-1}$ in $\mathrm{HL}^{1}$ and $1008 \mathrm{~cm}^{-1}$ in $\mathrm{HL}^{2}$. This vibration mode was calculated at ca. 1002 $\mathrm{cm}^{-1}$ for both imine oximes. The out-of-plane bending vibration of this mode for $\mathrm{HL}^{1}$ and $\mathrm{HL}^{2}$ was calculated at 347 and $351 \mathrm{~cm}^{-1}$, respectively. All these bands are found in the expected range which shows that NO bands remain independent in the present molecules also, as suggested in the literature. ${ }^{36,37}$

\subsection{NMR spectroscopy}

The chemical shifts obtained in experimental and calculated ${ }^{1} \mathrm{H}$ and ${ }^{13} \mathrm{C}$ NMR spectra of $\mathrm{HL}^{1}$ and $\mathrm{HL}^{2}$ in $\mathrm{CDCl}_{3}$ with TMS as a reference are given in Table S3 (in Supplementary Information), while the experimental and theoretical spectra are shown in Figures S4 and S5 (Supplementary Information). The numbering of the atoms is the same as in Figure 2. As can be seen from Table S3 (in Supplementary Information), the NMR shifts calculated by the DFT method at the B3LYP/6$311++\mathrm{G}(\mathrm{d}, \mathrm{p})$ level are in reasonable agreement with the experimental values. The deuterium exchangeable proton of the hydroxyimino group $(-\mathrm{C}=\mathrm{N}-\mathrm{OH})$ shows a characteristic chemical shift at 10.96 and $10.77 \mathrm{ppm}$ as singlet for $\mathrm{HL}^{1}$ and $\mathrm{HL}^{2}$, respectively. This chemical shift was calculated as 8.36 and 8.39 ppm, respectively for both imine oximes. ${ }^{36}$ The 8 protons of the methyl/mehylene groups for $\mathrm{HL}^{1}$ and the 10 protons for $\mathrm{HL}^{2}$ were observed between 4.88 and $1.02 \mathrm{ppm}$ as singlet, doublet or multiplet, and these chemical shifts were calculated as 4.99 and $0.91 \mathrm{ppm}$. In addition, the multiple peaks between 8.56 and 7.11 ppm represent the aromatic protons of pyridine group and they were calculated as 8.93 and $7.47 \mathrm{ppm}$ for both imine oximes.

${ }^{13} \mathrm{C}$ NMR spectra for $\mathrm{HL}^{1}$ and $\mathrm{HL}^{2}$ show 10 and 11 different carbon atoms. The signal at $169.2 \mathrm{ppm}$ belongs to the $\mathrm{C} 2$ carbon atom and was calculated at $173.9 \mathrm{ppm}$ in $\mathrm{HL}^{1}$, while this chemical shift was observed $170.6 \mathrm{ppm}$ (calcd. 177.8) in $\mathrm{HL}^{2}$. The carbon resonance of the $\mathrm{C}=\mathrm{N}-\mathrm{OH}$ group for $\mathrm{HL}^{1}$ and $\mathrm{HL}^{2}$ was measured at 159.2 and 160.4 ppm, respectively, as expected for imine oximes. ${ }^{36,37}$ This chemical shift was calculated as 167.3 and $167.5 \mathrm{ppm}$, respectively, for both imine oximes. The signals between 157.0 and $122.1 \mathrm{ppm}$ are assigned to both pyridine carbon atoms and compare well with the calculated values. The C3, C9 and C10 resonances were observed at 57.9, 11.8 and $16.5 \mathrm{ppm}$, respectively, for $\mathrm{HL}^{1}$, while these carbon atoms were calculated at 60.7, 7.3 and $12.2 \mathrm{ppm}$, respectively. In the spectrum of $\mathrm{HL}^{2}$, the aliphatic carbons which are $\mathrm{C} 3, \mathrm{C} 9, \mathrm{C} 10$ and $\mathrm{C} 11$ were measured 56.1, 20.8, 11.3 and $9.4 \mathrm{ppm}$, respectively, while these carbon atoms were calculated as 59.3 and 7.7 ppm.

\subsection{DNA binding studies}

Molecular docking can particularly indicate the characteristics of the interaction between DNA at the molecular level. It was carried out to discuss the binding modes using AutoDock/Vina program for the interactions of $\mathrm{HL}^{1}$ and $\mathrm{HL}^{2}$ molecules with DNA fragments. The docking properties were investigated for the three lowest-energy conformations of the both imine oximes, and the docked structures are shown in Figure S6 (Supplementary Information).

As seen Figure S6, the docking structures for the three conformers of the both imine oximes are similar. Although the most stable molecular structure is $s$-trans, the $s$-cis structure is adopted by highest binding energy in the docking process. The binding free energies of the docked structures were computed to be -26.78 , $-27.61,-26.36 \mathrm{~kJ} \mathrm{~mol}^{-1}$ for 1,2 and 3 of $\mathrm{HL}^{1}$, respectively, and $-26.36,-27.19$ and $-26.78 \mathrm{~kJ} \mathrm{~mol}^{-1}$ for 1 , 2 and 3 of $\mathrm{HL}^{2}$, respectively. These results indicate greater binding affinity of 2 relative to other structures for both imine oximes. Therefore, energetically the most favorable docked structure obtained from the rigid 
molecular docking of 1BNA (B-DNA) is shown in Figure 3. It revealed the bindings of $\mathrm{HL}^{1}$ and $\mathrm{HL}^{2}$ with the minor groove of targeted DNA towards G-C rich region.

$\mathrm{HL}^{1}$ is mainly stabilized by hydrogen bondings through the $\mathrm{OH}$ group of the $\mathrm{HL}^{1}$ ligand with $\mathrm{O} 2$ of cytosine and $\mathrm{N} 2 \mathrm{H} 21$ of guanine with $\mathrm{N} 3$ of the $\mathrm{HL}^{1}$, while the interaction of $\mathrm{HL}^{2}$ with DNA is also via two hydrogen bonds, which are between $\mathrm{HL}^{2}$ and guanine. First, the oxime hydroxyl $\mathrm{O}$ in $\mathrm{HL}^{2}$ was at $2.08 \AA$ from $\mathrm{N} 2$ hydrogen atom of DG-22, and the other is between $\mathrm{O} 1 \mathrm{H}$ and $\mathrm{O} 4 /$ of DG4. The distances of the all hydrogen bonds are listed in Table 1.

\subsection{Docking with HSA}

As is known, the binding of ligands to protein is exceedingly important, because it can greatly influence the distribution and elimination of the ligand, as well as the duration and intensity of its pharmacological and toxicological functions. ${ }^{48,49}$ In view of this, it is important to know the specific binding mode and binding region of $\mathrm{HL}^{1}$ and $\mathrm{HL}^{2}$ at $\mathrm{HSA}$. In order to reveal the most likely binding mode and binding region of the three most stable conformers of $\mathrm{HL}^{1}$ and $\mathrm{HL}^{2}$ on HSA, the Autodock 4.0/Vina program was used. The crystal structure of HSA in complex was obtained from the

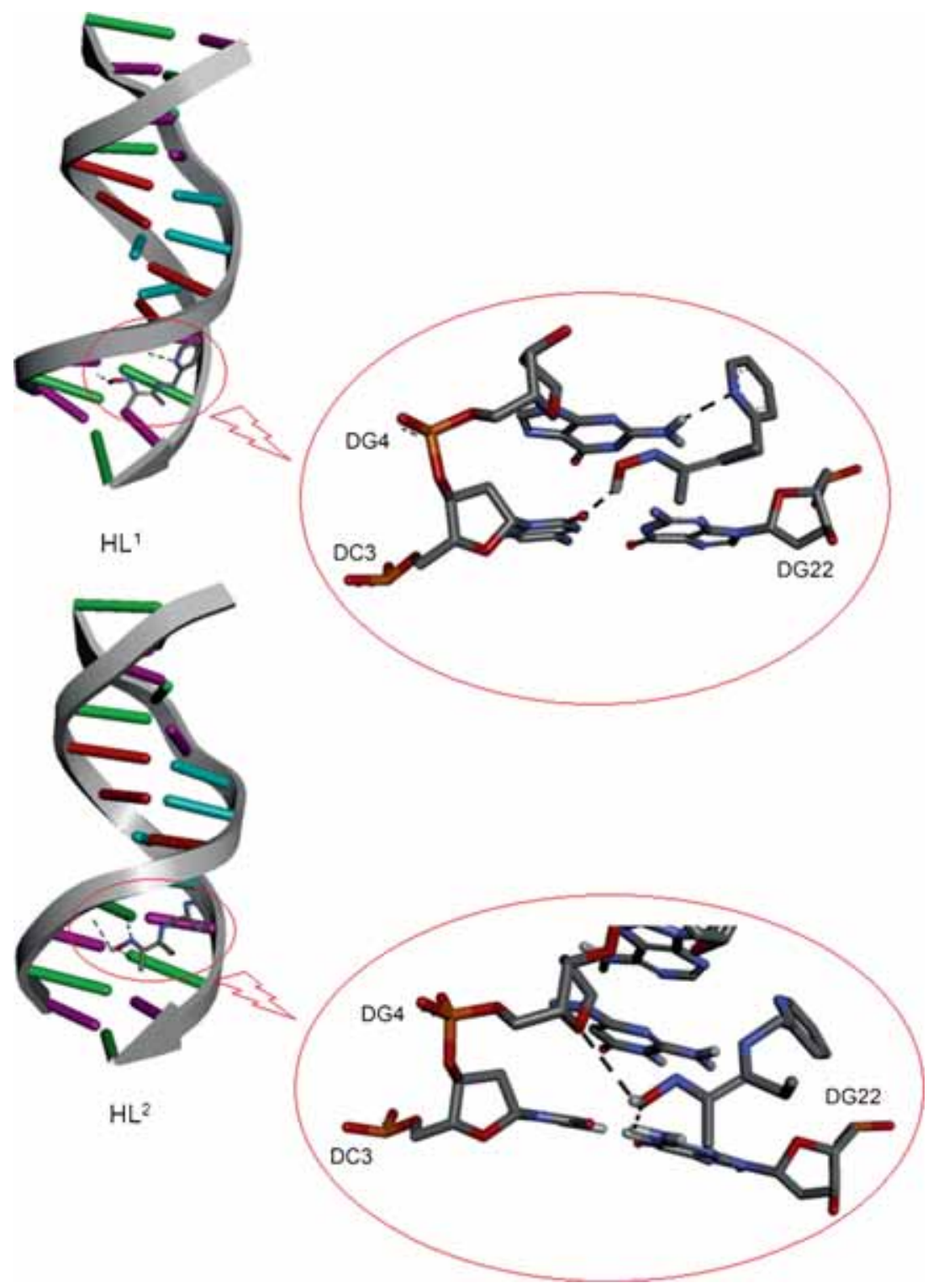

Figure 3. Molecular docking of the most favorable docked structures for $\mathrm{HL}^{1}$ and $\mathrm{HL}^{2}$. The molecules interact with DNA adjacent to the $\mathrm{G} / \mathrm{C}$ rich sequence of the minor groove. 
Table 1. Hydrogen bonding interactions and the binding free energy of the most stable docking conformations for $\mathrm{HL}^{1}$ and $\mathrm{HL}^{2}$ docked onto DNA and HSA.

\begin{tabular}{|c|c|c|c|c|c|}
\hline Molecule & Donor (D-H) & Acceptor $(\mathrm{H} \cdots \mathrm{A})$ & $\begin{array}{l}\text { Distance } \\
(\mathrm{H} \cdots \mathrm{A}, \AA)\end{array}$ & $\begin{array}{l}\text { Affinity energy } \\
(\mathrm{kJ} / \mathrm{mol})\end{array}$ & $\begin{array}{l}\text { Responsible protein } \\
\text { interaction }\end{array}$ \\
\hline \multicolumn{6}{|l|}{$D N A$} \\
\hline \multirow[t]{2}{*}{$\mathrm{HL}^{1}$} & $\mathrm{O} 1 \mathrm{H}\left(\mathrm{HL}^{1}\right)$ & $\begin{array}{l}\mathrm{O} 2 \text { (DC-3) } \\
\text { (DNA-chain A) }\end{array}$ & 2.13 & -27.61 & \\
\hline & $\begin{array}{l}\text { N2H21 (DG-4) } \\
\text { (DNA-chain A) }\end{array}$ & $\mathrm{N} 3\left(\mathrm{HL}^{1}\right)$ & 2.25 & & \\
\hline \multirow[t]{2}{*}{$\mathrm{HL}^{2}$} & $\begin{array}{l}\text { N2H22 (DG-22) } \\
\text { (DNA-chain B) }\end{array}$ & $\mathrm{O} 1 \mathrm{H}\left(\mathrm{HL}^{2}\right)$ & 2.18 & -27.20 & \\
\hline & $\mathrm{O} 1 \mathrm{H}\left(\mathrm{HL}^{2}\right)$ & $\begin{array}{l}\text { O4'(DG-4) } \\
\text { (DNA-chain A) }\end{array}$ & 2.36 & & \\
\hline \multicolumn{6}{|l|}{ Protein } \\
\hline \multirow[t]{2}{*}{$\mathrm{HL}^{1}$} & NEHE (Arg257) & $\mathrm{O} 1\left(\mathrm{HL}^{1}\right)$ & 2.64 & -31.80 & $\begin{array}{l}\text { Trp214, His242, } \\
\text { Arg257, Ser87 }\end{array}$ \\
\hline & N2H21 (Arg257) & $\mathrm{O} 1\left(\mathrm{HL}^{1}\right)$ & 2.87 & & \\
\hline $\mathrm{HL}^{2}$ & ND1HD1 (His242) & $\mathrm{N} 2\left(\mathrm{HL}^{2}\right)$ & 2.85 & -31.38 & Trp214, His 242 \\
\hline
\end{tabular}

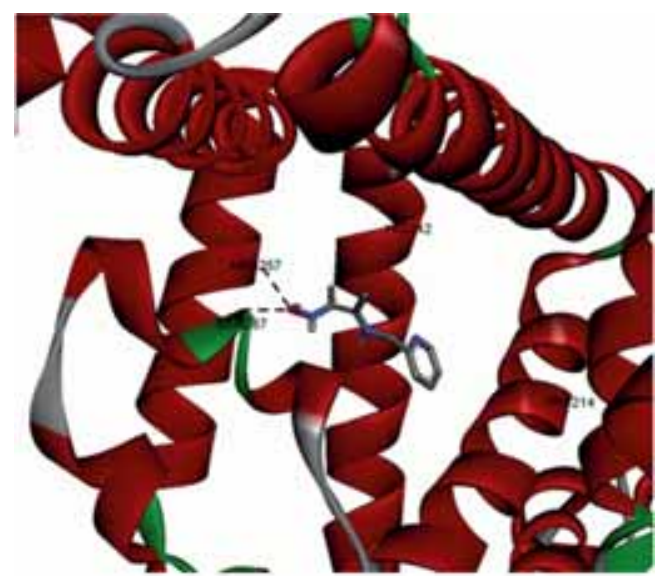

$\mathrm{HL}^{1}$

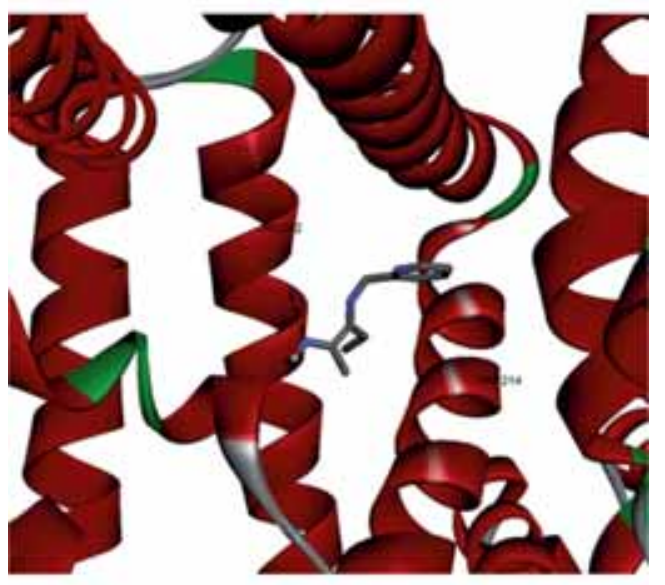

$\mathrm{HL}^{2}$

Figure 4. Molecular docking of the most favorable docked structures for $\mathrm{HL}^{1}$ and $\mathrm{HL}^{2}$ in subdomain IIA of HSA.

PDB database and Autodock 4.0 molecular modeling software was used to generate the initial structures of all the molecules. HSA has three structurally homologous domains: I (residues 1-195), II (196-383), and III (384-585), each of which are subdivided into subdomains A and B. The principal drug binding sites of HSA are mainly located in the subdomain IIA and IIIA. ${ }^{50}$ The dominating configurations of the s-cis and s-trans conformers of $\mathrm{HL}^{1}$ and $\mathrm{HL}^{2}$-HSA complex with the lowest binding free energy are shown in Figure S7 (Supplementary Information). The binding free energies of the molecular docking structures with HSA were computed to be $-30.54,-31.80,-30.96 \mathrm{~kJ} \mathrm{~mol}^{-1}$ for 1,2 and 3 of $\mathrm{HL}^{1}$, respectively and $-30.54,-31.38$ and -30.54 $\mathrm{kJ} \mathrm{mol}^{-1}$ for 1,2 and 3 of $\mathrm{HL}^{2}$, respectively (Table 1). These results indicate greater binding affinity of 2 relative to other molecule modes for both imine oximes, which are shown in Figure 4. Molecular docking studies revealed that the most stable conformers of the $\mathrm{HL}^{1}$ and $\mathrm{HL}^{2}$ are surrounded by the residues (within $3.5 \AA$ ) Trp214, His242, Arg257 and Ser287 (Figure 4). The $\mathrm{HL}^{1}$ and $\mathrm{HL}^{2}$ enter a hydrophobic cavity in subdomain IIA of HSA. Moreover, in addition to the $\mathrm{HL}^{1}$ and $\mathrm{HL}^{2}$ hydrogen bonds with HSA involving the $\mathrm{N}$ and $\mathrm{O}$ atoms of imine oximes, which are listed in Table 1, electrostatic interactions are also present. Docking of the both imine oximes with HSA demonstrated that all the molecules interact with the single tryptophan residue (Trp214) in subdomain IIA of HSA. These preliminary results suggest that $\mathrm{HL}^{1}$ and $\mathrm{HL}^{2}$ might exhibit inhibitory activity against protein HSA.

\section{Conclusions}

In this study, two flexible imine oxime compounds, namely, 3-(pyridin-2-ylmethylimino)-butan-2-one oxime 
$\left(\mathrm{HL}^{1}\right)$ and 3-(pyridin-2-ylmethylimino)-pentan-2-one oxime $\left(\mathrm{HL}^{2}\right)$ have been synthesized and characterized by various techniques including elemental analysis, IR, NMR spectroscopy. Conformational analysis was carried out for both imine oximes at B3LYP/6$311++\mathrm{G}(\mathrm{d}, \mathrm{p})$ level, and then the stable three conformers were determined. The most stable conformer was calculated s-trans isomer, for which dihedral angles N1-C1-C2-N2 were computed as ca. $-178^{\circ}$ for both imine oximes. The spectroscopic data such as vibrational and NMR chemical shifts were calculated for the most stable conformer, and compared with experimental results. IR spectra analyses showed that the predicted vibrational frequencies are in good agreement with the experimental values. In the binding calculations, the three most stable conformers were used. Both DNA docking and HSA binding studies showed that the s-cis isomer of both imine oximes docked with highest binding energy. The highest binding energy was observed for 'structure 2' for $\mathrm{HL}^{1}$ and $\mathrm{HL}^{2}$, which were calculated at ca. $27.7 \mathrm{kJmol}^{-1}$ for DNA docking, and at ca. $31.5 \mathrm{kJmol}^{-1}$ for HSA binding. Binding of $\mathrm{HL}^{1}$ and $\mathrm{HL}^{2}$ to DNA was through minor groove and to HSA via hydrophobic interaction in subdomain IIA.

\section{Supplementary Information (SI)}

All additional information pertaining to characterization of the molecules using elemental analysis (Table S1), IR data (Table S2), NMR data (Table S3), mass spectra (Figure S1), IR spectra (Figures S2 and S3) and NMR spectra (Figures S4 and S5). In addition, the dominating configurations of the s-cis and s-trans conformers of $\mathrm{HL}^{1}$ and $\mathrm{HL}^{2}$-DNA complex (Figure S6) and HSA complex (Figure S7) with the lowest binding free energy are given in Supporting Information, available at www.ias.ac.in/chemsci.

\section{Acknowledgements}

This work is a part of a research project $\operatorname{KUAP}(\mathrm{F})$ 2015/20 and OUAP(F)-2013/14. We thank Uludag University for the financial support.

\section{References}

1. Maekawa M, Kitagawa S, Nakao Y, Sakamoto S, Yatani A, Mori W, Kashino S and Munakata M 1999 Chim. Acta 29320

2. Reddy K H, Prasad N B L and Reddy T S 2003 Talanta 59425

3. Eltayeb M A Z and Sulfab Y 2007 Polyhedron 261

4. Neese F 2009 Coord. Chem. Rev. 53526
5. Jayaseelan P, Prasad S, Vedanayaki S and Rajavel R 2001 Eur. J. Chem. 2480

6. Maity D, Chattopadhyay S, Ghosh A, Drew M G B and Mukhopadhya G 2011 Inorg. Chim. Acta 36525

7. Chakravorty A 1974 Coord. Chem. Rev. 131

8. Packard A B, Kronauge J F, Day P J and Treves S T 1998 Nucl. Med. Biol. 25531

9. Zangrando E, Trani M, Stabon E, Carfagna C, Milani B and Mestroni G 2683 Eur. J. Inorg. Chem.

10. Hambley T W, Ling E C H, O’Mara S, McKeage M J and Russell P J 2000 J. Biol. Inorg. Chem. 5675

11. Ling E C H, Allen G W, Vickery K and Hambley T W 2000 J. Inorg. Biochem. 7855

12. Dodoff N I et al. 2009 Chemija 20208

13. Xu Z and Zhou L 2011 Int. J. Quantum Chem. 1111907

14. Malek K, Vala M, Kozlowski H and Proniewicz L M 2004 Magn. Reson. Chem. 4223

15. Jones R M, Goldcamp M J, Krause J A and Baldwin M J 2006 Polyhedron 253145

16. Georgieva I and Trendafilova Nand Bauer G 2006 Spectrochim. Acta Part A 63403

17. Luzyanin K V, Kukushkin V Yu, Kuznetsov M L, Ryabov A D, Galanski M, Haukka M, Tretyakov E V, Ovcharenko V I, Kopylovich M N and Pombeiro A J L 2006 Inorg. Chem. 452296

18. Lalia-Kantouri M, Papadopoulos C D, Quirós M and Hatzidimitrious A G 2007 Polyhedron 261292

19. Palacios M A, Mota A J, Perea-Buceta J E, White F J, Brechin E K and Colacio E 2010 Inorg. Chem. 4910156

20. Serbest K, Karaoglu K, Erman M, Er M and Değirmencioğlu I 2010 Spectrochim. Acta A 77643

21. Proft F D and Geerlings P 2001 Chem. Rev. 1011451

22. Becke A D 1993 J. Chem. Phys. 985648

23. Frisch M J et al. 2004 In Gaussian 03, Rev. E.01 (Gaussian, Inc.: Wallingford, CT)

24. Sundaraganesan N, Illakiamani S, Saleem H, Wojciechowski P M and Michalska D 2005 Spectrochim. Acta A 612995

25. Jesus A J L, Rosado M T S, Reva I, Fausto R, Eusébio M E and Redinha J S 2006 J. Phys. Chem. A 1104169

26. Jamroz M H 2004-2010, Vibrational Energy Distribution Analysis VEDA 4, Warsaw, Poland

27. Wolinski K, Hinton J F and Pulay P 1990 J. Am. Chem. Soc. 1128251

28. Trott $\mathrm{O}$ and Olson A J 2010 J. Comput. Chem. 31455

29. Colthup N B, Daly L H and Wiberley S E 1990 In Introduction to Infrared and Raman Spectroscopy (New York: Academic Press)

30. Smith B C 1996 In Infrared Spectral Interpretation (Boca Raton, FL: CRC Press)

31. Green J H S, Harrison D J and Kynaston W 1971 Spectrochim. Acta A 272199

32. Varsanyi G 1974 In Assignments for Vibrational Spectra of Seven Hundred Benzene Derivatives. Vols. 1 and 2 (Budapest: Adam Hilger)

33. Lutz E T G and Mass J H V 1986 Spectrochim. Acta A 42749 
34. Sathyanarayana D N 2004 In Vibrational Spectroscopy Theory and Applications 2nd ed. (New Delhi: New Age International)

35. Manimekalaia A and Balachander R 2012 Magn. Reson. Chem. $\mathbf{5 0} 765$

36. Kaya Y, Yilmaz V T, Arslan T and Buyukgungor O 2012 J. Mol. Struct. 102465

37. Kaya Y, Icsel C, Yilmaz V T and Buyukgungor O 2013 J. Organomet. Chem. $\mathbf{7 5 2} 83$

38. Krishnakumar V, Manohar S and Nagalakshmi R 2008 Spectrochim. Acta A 71110

39. Castro M E, Percino M J, Chapela V M, Ceron M, Soriano-Moro G, Lopez-Cruz J and Melendez F J 2013 Int. J. Mol. Sci. 144005

40. Li Y, Liu Y Y, Chen X J, Xiong X H and Li F S 2014 PLoS One 91

41. Singh H J and Sirivastava P 2009 Indian J. Pure Appl. Phys. 47557
42. Boopathi M, Udhayakala P, Ramkumaar G R, Rajendiranand T V and Gunasekaran S 2015 Der Pharma Chemica 7110

43. Arjunan V, Puviarasan N and Mohan S 2006 Spectochim. Acta A 64233

44. Altun A, Golcuk K and Kumru M 2003 J. Mol. Struct. Theochem. 637155

45. Muthu S, Ramachandran G and Uma Maheswari J 2012 Spectochim. Acta A 93214

46. Al-Hokbany N S, Dahy A A, Warad I K H and Mahfouz R 2012 J. Chem. 92191

47. Socrates G 2001 In Infrared and Raman Characteristic Group Frequencies - Tables and Charts 3rd ed. (Chichester: John Wiley)

48. Zhang X H, Liu L N, Lin Y J and Lin C W 2013 Luminescence 28419

49. Endo S and Goss K 2011 Chem. Res. Toxicol. 242293

50. He X M and Carter D C 1992 Nature 358209 